\title{
Financial Statement Analysis of Beximco Synthetics Limited
}

\author{
K. M. Anwarul Islam ${ }^{1}$ \\ ${ }^{1}$ Department of Business Administration, The Millennium University, Dhaka, Bangladesh \\ Correspondence: Department of Business Administration, The Millennium University, Dhaka, Bangladesh, \\ E-mail: ai419bankingdu@gmail.com \\ Received: October 04, 2017 \\ Accepted: October 18, 2017 \\ Online Published: October 30, 2017

\begin{abstract}
This paper deals with the Financial Statement analysis of Beximco Synthetics Ltd. to get a practical view of how analysis is done using financial statements. We have taken the four year's (2010-2013) financial statements of the company to complete the whole analysis. In ratio analysis we calculated various ratios such as Internal Liquidity Ratios, Operating Efficiency Ratios, and Ratios for Risk Analysis and Operating Profitability Ratios etc. At first the financial statements were reformulated to get pure views of the trends regarding different items of the statements.
\end{abstract}

Keywords: Financial Statement Analysis, BSL, Ratio Analysis, DUPONT Analysis.

\section{Introduction}

The study of financial statements helps investment decisions by revealing information on the financial statements that is relevant to the decisions. The objective of the assessment is to determine the financial health of the company based on financial statements. To better financial statement analysis, much empirical accounting research has attempted to identify and measure value-relevant accounting qualities. Assumption is made in this study that market pricing acts as a suitable standard to compare firms' values and so serves as a reference for the accounting information. Accounting qualities are correlated with stock prices, therefore they might be seen as value-relevant. Several preceding 'information content' publications are the likes of Ball and Brown (1968) and their successors, and together, they demonstrate that accounting earnings and some of its constituents encapsulate market information.

\section{Literature Review}

Feroz, Kim, and Raab (2003) Ratio analysis is frequently used to assess the efficiency of a business. Another important reason why ratios are so widely accepted is that they are rather simple to calculate. Additionally, their interpretation is a source of confusion, particularly when two or more ratios send opposing messages. A last criticism of ratio analysis is that it is subjective because it is the analyst's job to choose ratios to evaluate the overall performance of a company.

Damitio, Schmidgall, and Dennington (1995) A few different ways exist for analyzing the Statement of 
An Empirical Research on Shinepukur Holdings Ltd: Strategy, Accounting, Ratio, Sensitivity and Prospective Analysis

Cash Flows. The most common is the preparation of comparative statements of cash flows, while a less common technique is the use of ratio analysis. This article analyzes the financial accounts of a fictitious hotel, the Example Inn, using these financial statement analysis methods.

Standard-Setters (2002) An investigation of whether the manner financial reporting is done is affected by country cultures is performed by the writers. Three groups of professional accountants from the same large multinational accounting firm is used to carry out an experiment where the same financial information about two fake companies is presented to three separate sets of accountants, who hail from three different nations.

Because the accounting regulations governing warranties are the same in every country, the accountants calculate warranty expenses for warranties (returned products). When investigating which figures may be considered "average," the authors discover that the estimations in the three nations vary greatly.

Gross leverage is the total liabilities of a business versus its equity. Many liabilities, like debt issued by banks or government agencies, are created through finance; however, other liabilities, such payables to suppliers, customers, and workers, result from doing business. In healthy capital markets, liabilities are often traded as price takers. However, since the input and output markets are imperfect compared to the capital markets, firms are able to add value in their operations. Operating liabilities, which originate in day-to-day business operations, have certain characteristics that bear similarity to those of liabilities created by external sources.

\section{Analysis of Data}

For ratio analysis, we have chosen Beximco Synthetics Limited. Here we have taken 4 years of data and our first calendar year of data is 2010 .

Our Findings

By using the provided Ratio Analysis Template, we have found the following ratios:

\begin{tabular}{|c|c|c|c|c|}
\hline \multirow[t]{2}{*}{ Ratio } & \multicolumn{4}{|c|}{ Year } \\
\hline & 2010 & 2011 & 2012 & 2013 \\
\hline Current Ratio & 1.09 & 1.30 & 1.18 & 1.31 \\
\hline Quick Ratio & 0.30 & 0.42 & 0.36 & 0.37 \\
\hline Inventory Turnover & 1.07 & 1.06 & 0.98 & 1.07 \\
\hline Average Collection Period & 24.47 & 51.41 & 55.57 & 46.88 \\
\hline Fixed Asset Turnover & 1.38 & 1.47 & 1.68 & 2.07 \\
\hline Total Asset Turnover & 0.57 & 0.55 & 0.55 & 0.62 \\
\hline Debt Ratio & 0.61 & 0.57 & 0.57 & 0.54 \\
\hline Debt to Equity & 0.19 & 0.21 & 0.00 & 0.00 \\
\hline Times Interest Earned & 2.32 & 2.09 & 2.04 & 2.16 \\
\hline Gross Profit Margin & $21.90 \%$ & $18.48 \%$ & $16.29 \%$ & $13.33 \%$ \\
\hline Operating Profit Margin & $19.37 \%$ & $15.94 \%$ & $13.73 \%$ & $10.96 \%$ \\
\hline Net Profit Margin & $10.50 \%$ & $6.36 \%$ & $3.69 \%$ & $3.44 \%$ \\
\hline Return on Total Assets (ROA) & $6.02 \%$ & $3.51 \%$ & $2.03 \%$ & $2.14 \%$ \\
\hline Return on Equity (ROE) & $15.26 \%$ & $8.17 \%$ & $4.72 \%$ & $4.57 \%$ \\
\hline Earnings Per Share (EPS) & TK 28.37 & TK 16.54 & TK 9.48 & TK 9.22 \\
\hline Price/Earnings Ratio & 6.11 & 8.17 & 10.55 & 8.73 \\
\hline
\end{tabular}


An Empirical Research on Shinepukur Holdings Ltd: Strategy, Accounting, Ratio, Sensitivity and Prospective Analysis

And we have found the following results for DUPONT Analysis:

\begin{tabular}{|c|c|c|c|c|}
\hline \multirow{2}{*}{ Ratio } & \multicolumn{3}{|c|}{ Year } \\
\cline { 2 - 5 } & 2010 & 2011 & 2012 & 2013 \\
\hline Net profit AT/Sales & $10.50 \%$ & $6.36 \%$ & $3.69 \%$ & $3.44 \%$ \\
\hline Sales/Total Assets & $57.36 \%$ & $55.20 \%$ & $54.93 \%$ & $62.13 \%$ \\
\hline ROA & $6.02 \%$ & $3.51 \%$ & $2.03 \%$ & $2.14 \%$ \\
\hline Net profit AT/Total Assets & $6.02 \%$ & $3.51 \%$ & $2.03 \%$ & $2.14 \%$ \\
\hline Total Assets/Stockholders Equity & $253.40 \%$ & $232.81 \%$ & $232.64 \%$ & $213.87 \%$ \\
\hline ROE & $15.26 \%$ & $8.17 \%$ & $4.72 \%$ & $4.57 \%$ \\
\hline
\end{tabular}

\section{Interpretation of Ratios}

\section{- Current Ratio}

Current Ratio shows the ability to meet future short term financial obligation. Here we have the following current ratios of Beximco Synthetics:

\begin{tabular}{|l|l|l|l|l|}
\hline Year & $\mathbf{2 0 1 0}$ & $\mathbf{2 0 1 1}$ & $\mathbf{2 0 1 2}$ & $\mathbf{2 0 1 3}$ \\
\hline Current Ratio & 1.09 & 1.30 & 1.18 & 1.31 \\
\hline
\end{tabular}

As in all the years' current ratio is more than 1.00, it indicates good payment ability of the company. If it would be more than or equal to 2 , then it would have more payment capacity.

\section{- Quick Ratio}

It indicates the speed of payment of a company. Here we have the following ratios:

\begin{tabular}{|l|l|l|l|l|}
\hline Year & $\mathbf{2 0 1 0}$ & $\mathbf{2 0 1 1}$ & $\mathbf{2 0 1 2}$ & $\mathbf{2 0 1 3}$ \\
\hline Quick Ratio & 0.30 & 0.42 & 0.36 & 0.37 \\
\hline
\end{tabular}

From the above data, we find that the ratios of the company are being increased year to year on an average. As it is below 1.00, we conclude that the Company is not in a satisfactory position in cash payment.

\section{- Inventory Turnover}

This ratio indicates the liquidity position of a company. Here we have the following inventory turnovers over the 4 years.

\begin{tabular}{|l|l|l|l|l|}
\hline Year & $\mathbf{2 0 1 0}$ & $\mathbf{2 0 1 1}$ & $\mathbf{2 0 1 2}$ & $\mathbf{2 0 1 3}$ \\
\hline Inventory Turnover & 1.07 & 1.06 & 0.98 & 1.07 \\
\hline
\end{tabular}

In 2010 and 2013, the company was in better position during the considered 4 years. 
An Empirical Research on Shinepukur Holdings Ltd: Strategy, Accounting, Ratio, Sensitivity and Prospective Analysis

- Average Collection Period

\begin{tabular}{|l|l|l|l|l|}
\hline Year & $\mathbf{2 0 1 0}$ & $\mathbf{2 0 1 1}$ & $\mathbf{2 0 1 2}$ & $\mathbf{2 0 1 3}$ \\
\hline Average Collection Period & 24.47 & 51.41 & 55.57 & 46.88 \\
\hline
\end{tabular}

In 2012, the company's average collection period is 55.57 days. It is the worst collection efficiency of the company. Again, the company is in good position in collection in 2010 while its period is only 24.47 days.

\section{- Fixed Asset Turnover}

It reflects the utilization of the fixed asset. Over the years, the turnovers are as follows:

\begin{tabular}{|l|l|l|l|l|}
\hline Year & $\mathbf{2 0 1 0}$ & $\mathbf{2 0 1 1}$ & $\mathbf{2 0 1 2}$ & $\mathbf{2 0 1 3}$ \\
\hline Fixed Asset Turnover & 1.38 & 1.47 & 1.68 & 2.07 \\
\hline
\end{tabular}

The company's turnover is being increased year to year. Its growth rate is pretty good. The company had turnover 2.07 in 2013. It indicates that the company's fixed asset turnover is more than double of its fixed asset utilization capacity.

\section{- Total Asset Turnover}

This turnover ratio indicates the effectiveness of a firm's use of its total asset base. The findings are:

\begin{tabular}{|l|l|l|l|l|}
\hline Year & $\mathbf{2 0 1 0}$ & $\mathbf{2 0 1 1}$ & $\mathbf{2 0 1 2}$ & $\mathbf{2 0 1 3}$ \\
\hline Total Asset Turnover & 0.57 & 0.55 & 0.55 & 0.62 \\
\hline
\end{tabular}

The highest turnover is in 2013 that is 0.62 . It is the highest turnover among the calculated years. It explains that the company is doing well year to year.

\section{- Debt Ratio}

\begin{tabular}{|l|l|l|l|l|}
\hline Year & $\mathbf{2 0 1 0}$ & $\mathbf{2 0 1 1}$ & $\mathbf{2 0 1 2}$ & $\mathbf{2 0 1 3}$ \\
\hline Debt Ratio & 0.61 & 0.57 & 0.57 & 0.54 \\
\hline
\end{tabular}

The Debt Ratio of the company is being decreased year to year. It is a good sign for the company as it lowers the financial risk as well as bankruptcy costs.

\section{- Debt-Equity Ratio}

The debt-equity ratios of the company for the last 4 accounting years have is given below in table:

\begin{tabular}{|l|l|l|l|l|}
\hline Year & $\mathbf{2 0 1 0}$ & $\mathbf{2 0 1 1}$ & $\mathbf{2 0 1 2}$ & $\mathbf{2 0 1 3}$ \\
\hline Debt to Equity & 0.19 & 0.21 & 0.00 & 0.00 \\
\hline
\end{tabular}

To have a clear understanding of these ratios, we present these in the following bar chart diagram: 


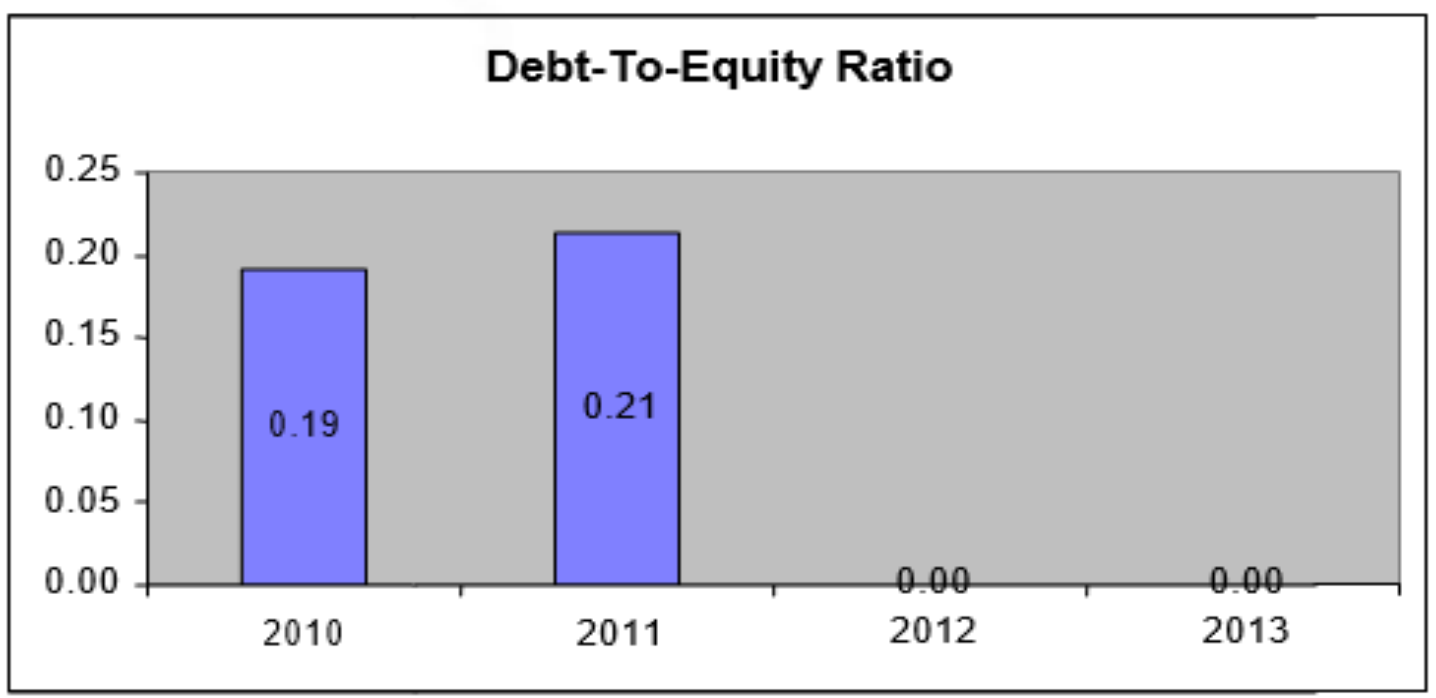

In year 2012 and 2013, there was no debt of Beximco Synthetics. But in previous two years the company had $19 \%$ and $21 \%$ respectively. It is good news for the common shareholders of the company.

\section{- Times Interest Earned}

\begin{tabular}{|c|c|c|c|c|}
\hline Year & $\mathbf{2 0 1 0}$ & $\mathbf{2 0 1 1}$ & $\mathbf{2 0 1 2}$ & $\mathbf{2 0 1 3}$ \\
\hline Times Interest Earned & 2.32 & 2.09 & 2.04 & 2.16 \\
\hline
\end{tabular}

\section{- Gross Profit Margin}

It is an indication of the extent to which revenue exceed direct cost associated with sells. It measures the rate of profit on sales.

\begin{tabular}{|c|c|c|c|c|}
\hline Year & $\mathbf{2 0 1 0}$ & $\mathbf{2 0 1 1}$ & $\mathbf{2 0 1 2}$ & $\mathbf{2 0 1 3}$ \\
\hline Gross profit margin & $21.90 \%$ & $18.48 \%$ & $16.29 \%$ & $13.33 \%$ \\
\hline
\end{tabular}

The company is in bad position in 2013 comparing to year 2010 as its gross profit margin has decreased to a great extent. It may have happened for increasing costs or decreasing of sales of the company.

\section{- Operating Profit Margin}

It measures the rate of profit on sales after operating expenses.

\begin{tabular}{|c|c|c|c|c|}
\hline Year & $\mathbf{2 0 1 0}$ & $\mathbf{2 0 1 1}$ & $\mathbf{2 0 1 2}$ & $\mathbf{2 0 1 3}$ \\
\hline Operating profit margin & $19.37 \%$ & $15.94 \%$ & $13.73 \%$ & $10.96 \%$ \\
\hline
\end{tabular}

From the data we see that the company's profit margin is being lowered year to year. Hence the company's operating efficiency is being decreased as well. It may have happened because of increasing cost of goods sold, or increasing operating costs, or decreasing sales volume. 
An Empirical Research on Shinepukur Holdings Ltd: Strategy, Accounting, Ratio, Sensitivity and Prospective Analysis

\section{- Net Profit Margin}

The data are as follows:

\begin{tabular}{|c|c|c|c|c|}
\hline Year & $\mathbf{2 0 1 0}$ & $\mathbf{2 0 1 1}$ & $\mathbf{2 0 1 2}$ & $\mathbf{2 0 1 3}$ \\
\hline Net profit margin & $10.50 \%$ & $6.36 \%$ & $3.69 \%$ & $3.44 \%$ \\
\hline
\end{tabular}

As gross profit margin and operating profit margin has decreased, this margin has decreased as well year to year. It tells us that the net income on net sales is being decreased. It is an indication of lower operating profitability of the company.

\section{- Return on Total Assets}

It tells us how much profit a company is able to generate for each TK of the assets invested.

\begin{tabular}{|c|c|c|c|c|}
\hline Year & $\mathbf{2 0 1 0}$ & $\mathbf{2 0 1 1}$ & $\mathbf{2 0 1 2}$ & $\mathbf{2 0 1 3}$ \\
\hline $\begin{array}{c}\text { Return on Total Assets } \\
\text { (ROA) }\end{array}$ & $6.02 \%$ & $3.51 \%$ & $2.03 \%$ & $2.14 \%$ \\
\hline
\end{tabular}

The company's return on assets is lowest in $2013,2.14 \%$ and highest in $2010,6.02 \%$. Its growth rate is negative. So it's not a good situation for the company for their invested assets. It may have resulted because of increasing of invested assets but not increasing of sales volume in the same rate.

\section{- Return on Equity}

It is a comprehensive indicator of company's performance because it provides and indicates how well managers are implying the funds invested by the firm's shareholders to generate returns. The data of this ratio is given below:

\begin{tabular}{|c|c|c|c|c|}
\hline Year & $\mathbf{2 0 1 0}$ & $\mathbf{2 0 1 1}$ & $\mathbf{2 0 1 2}$ & $\mathbf{2 0 1 3}$ \\
\hline Return on Equity (ROE) & $15.26 \%$ & $8.17 \%$ & $4.72 \%$ & $4.57 \%$ \\
\hline
\end{tabular}

Generally it is a good sign if it is $10-14 \%$. But in 2013 and during the previous years, this rate is being decreased.

\section{- Earnings per Share}

It is the ratio that point out rate of earnings on each share.

\begin{tabular}{|c|c|c|c|c|}
\hline Year & $\mathbf{2 0 1 0}$ & $\mathbf{2 0 1 1}$ & $\mathbf{2 0 1 2}$ & $\mathbf{2 0 1 3}$ \\
\hline Earnings per Share (EPS) & TK 28.37 & TK 16.54 & TK 9.48 & TK 9.22 \\
\hline
\end{tabular}

To have a better understanding, we have presented the above data in graph:

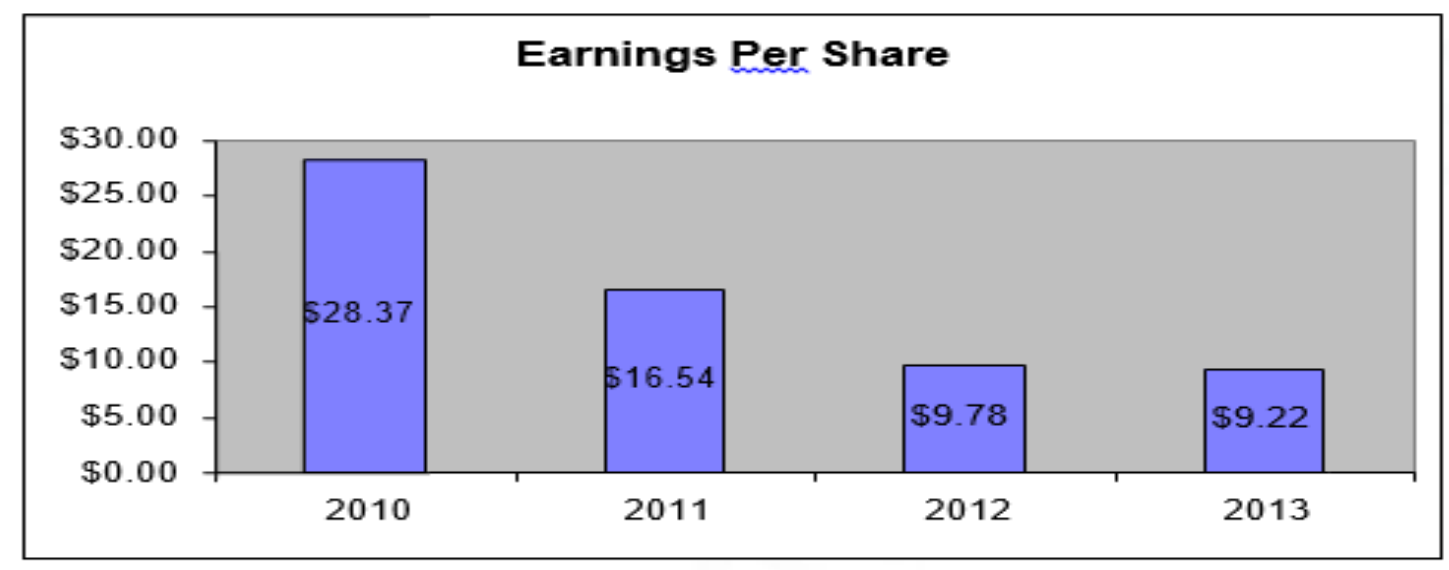


An Empirical Research on Shinepukur Holdings Ltd: Strategy, Accounting, Ratio, Sensitivity and Prospective Analysis

Here we find that EPS of Beximco Synthetics has been decreasing year to year. It is not a good sign for the company as well as company shareholders. In the year 2013, the company issued more 150,000 common shares. As a result, EPS decreased more in year 2013.

\section{- Price Earnings Ratio (EPS)}

\begin{tabular}{|c|c|c|c|c|}
\hline Year & $\mathbf{2 0 1 0}$ & $\mathbf{2 0 1 1}$ & $\mathbf{2 0 1 2}$ & $\mathbf{2 0 1 3}$ \\
\hline Price/Earnings ratio & 6.11 & 8.17 & 10.55 & 8.73 \\
\hline
\end{tabular}

Although price is decreasing year to year in Dhaka Stock Exchange, the amount of Price Earnings Ratio did not decrease. Besides, the EPS of the company has been decreasing as well. But the rate of decreasing of EPS was a little bit lower than Price growth. So the ratio has increased over the years.

The share price of Beximco Synthetics in DSE on 31 December in respective years was as follows:

\begin{tabular}{|c|c|c|c|c|}
\hline Year & 2010 & 2011 & 2012 & 2013 \\
\hline Share Price & TK 173.26 & TK 135.07 & TK 103.18 & TK 80.50 \\
\hline
\end{tabular}

\section{DUPONT Analysis}

\section{- Net profit AT/Sales}

\begin{tabular}{|c|c|c|c|c|}
\hline Year & $\mathbf{2 0 1 0}$ & $\mathbf{2 0 1 1}$ & $\mathbf{2 0 1 2}$ & $\mathbf{2 0 1 3}$ \\
\hline Net profit AT/Sales & $10.50 \%$ & $6.36 \%$ & $3.69 \%$ & $3.44 \%$ \\
\hline
\end{tabular}

The trend of net profit growth is decreasing. It is because the volume of cost of goods sold is increasing year to year. We have found that operating expense has not increased by this time rather it has decreased. So cost of goods sold is responsible for this decreasing growth.

- Sales/Total Assets

\begin{tabular}{|c|c|c|c|c|}
\hline Year & $\mathbf{2 0 1 0}$ & $\mathbf{2 0 1 1}$ & $\mathbf{2 0 1 2}$ & $\mathbf{2 0 1 3}$ \\
\hline Sales/Total Assets & $57.36 \%$ & $55.20 \%$ & $54.93 \%$ & $62.13 \%$ \\
\hline
\end{tabular}

We find that the ratio is highest in 2013. It has increased by $7.19 \%$ from year 2012. It is due to the decrease of total assets in 2013 .

- Return on Total Assets

\begin{tabular}{|c|c|c|c|c|}
\hline Year & $\mathbf{2 0 1 0}$ & $\mathbf{2 0 1 1}$ & $\mathbf{2 0 1 2}$ & $\mathbf{2 0 1 3}$ \\
\hline ROA & $6.02 \%$ & $3.51 \%$ & $2.03 \%$ & $2.14 \%$ \\
\hline
\end{tabular}

Here the ROA has increased by $0.11 \%$ in 2013 because of increase in sales and decrease in total assets.

- Total Assets/ Stockholders Equity

\begin{tabular}{|c|c|c|c|c|}
\hline Year & $\mathbf{2 0 1 0}$ & $\mathbf{2 0 1 1}$ & $\mathbf{2 0 1 2}$ & $\mathbf{2 0 1 3}$ \\
\hline $\begin{array}{c}\text { Total Assets / Stockholders } \\
\text { Equity }\end{array}$ & $253.40 \%$ & $232.81 \%$ & $232.64 \%$ & $213.87 \%$ \\
\hline
\end{tabular}

Here the percentage change of total assets in the first 3 years was less than the percentage change of stockholders equity. So the ratios have decreased over the years. In last year, 2003, the total assets have decreased but the stockholders equity has increased as well. So there is a significant decrease in this year. 
An Empirical Research on Shinepukur Holdings Ltd: Strategy, Accounting, Ratio, Sensitivity and Prospective Analysis

- Return on Equity (ROE)

\begin{tabular}{|c|c|c|c|c|}
\hline Year & $\mathbf{2 0 0 0}$ & $\mathbf{2 0 0 1}$ & $\mathbf{2 0 0 2}$ & $\mathbf{2 0 0 3}$ \\
\hline ROE & $15.26 \%$ & $8.17 \%$ & $4.72 \%$ & $4.57 \%$ \\
\hline
\end{tabular}

As the net income of the company over the years has decreased, but the stockholders equity has increased over the years, so the ROE of the company has decreased to a great extent over the years. In year 2012 and 2013, the percentage change is less comparing to previous years. It is because in 2013 , the stockholders equity has increased.

\section{Conclusion}

The company was in bad position in 2013 comparing to year 2010 as its gross profit margin has decreased to a great extent. It may have happened for increasing costs or decreasing of sales of the company. The company's profit margin is being lowered year to year. Hence the company's operating efficiency is being decreased as well. It may have happened because of increasing cost of goods sold, or increasing operating costs, or decreasing sales volume. As gross profit margin and operating profit margin has decreased, this margin has decreased as well year to year. It tells us that the net income on net sales is being decreased. It is an indication of lower operating profitability of the company. The company's return on assets is lowest in 2013, 2.14\% and highest in 2010, 6.02\%. Its growth rate is negative. So it's not a good situation for the company for their invested assets. It may have resulted because of increasing of invested assets but not increasing of sales volume in the same rate. Generally it is a good sign if ROE is 10- 14\%. But in 2003 and during the previous years, this rate is being decreased. Although price is decreasing year to year in Dhaka Stock Exchange, the amount of Price Earnings Ratio did not decrease. Besides, the EPS of the company has been decreasing as well. But the rate of decreasing of EPS was a little bit lower than Price growth. So the ratio has increased over the years.

\section{References}

Ball, R. \& P. Brown. (1968). An empirical evaluation of accounting income numbers, Journal of Accounting Research, Autumn, 159-178

Damitio, J., Schmidgall, R. S., \& Dennington, L. J. (1995). Financial statement analysis. Bottomline, 10(6), $10-23$.

Feroz, E. H., Kim, S., \& Raab, R. L. (2003). Financial statement analysis: A data envelopment analysis approach, Journal of theoperational Research Society, 54(1), 48-58.

Nissim, D., \& Penman, S. H. (2003). Financial statement analysis of leverage and how it informs about profitability and price-to-book ratios. Review of Accounting Studies, 8(4), 531-560

Standard-Setters, A. (2002). Financial statement analysis. TheCFA Digest.

\section{Copyrights}

Copyright for this article is retained by the author(s), with first publication rights granted to the journal. 